\title{
Global Stratotype Section and Point for base of the Ordovician System
}

1 Institute of Geological and Nuclear Sciences, P.O. Box 30368, Lower Hutt, New Zealand.

2 Geological Survey of Canada, 3303 - 33rd Street N.W., Calgary, Alberta, Canada T2L 2A7.

3 Department of Earth Sciences, Memorial University of Newfoundland, St. John's, Newfoundland, Canada A1B 3X5.

The Global Stratotype Section and Point for base of the Ordovician System and base of the lowest Ordovician stage (Tremadocian) is exposed in the coastal platform at Green Point, western Newfoundland, at the $101.8 \mathrm{~m}$ level, within Bed 23, in the measured section (Lower Broom Point Member, Green Point Formation), coinciding with the first appearance of the conodont Iapetognathus fluctivagus Nicoll, Miller, Nowlan, Repetski and Ethington, 1999, and $4.8 \mathrm{~m}$ below the earliest planktic graptolites.

\section{Introduction}

The Ordovician is the last of the Paleozoic Periods (and Systems) to have its lower boundary formally designated. The International Working Group on the Cambrian-Ordovician Boundary (COBWG) reached a decision on its choice of Global Stratotype Section and Point (GSSP) for base of the Ordovician System in January 1999, 25 years after its inauguration. The decision was approved by the International Subcommission on Ordovician Stratigraphy (ISOS) in September 1999, by the Commission on Stratigraphy in November 1999, and by the International Union of Geological Sciences in January 2000.

The COBWG visited and examined candidate sections in Kazakhstan, China, Australia, Scandinavia, Britain and North America. Two volumes of papers on candidate boundary sections were published (Bassett and Dean, 1982, and a special 1988 issue of Geological Magazine v. 125, no. 4). In addition, two volumes of papers on the Dayangcha section alone have been published (Chen et al., 1985; 1986).

\section{The Green Point section}

In western Newfoundland, a Cambrian to Ordovician sequence of shale and carbonates (Cow Head Group) is preserved in several allochthonous thrust sheets (Humber Arm Allochthon) that represent a transect across the continental slope (James and Stevens, 1986; Figure 1a, 1b). The conodont sequence in stratigraphic sections through the boundary interval in the Cow Head Group has been described by Fåhraeus and Nowlan (1978), Bagnoli et al. (1987), Barnes (1988) and Pohler (1994) and includes the Cow Head, Broom Point north, Broom Point south, St Paul's Inlet Quarry, Martin Point and Green Point sections (representing proximal to distal sites across the continental slope). Debris flow conglomerates become increas-

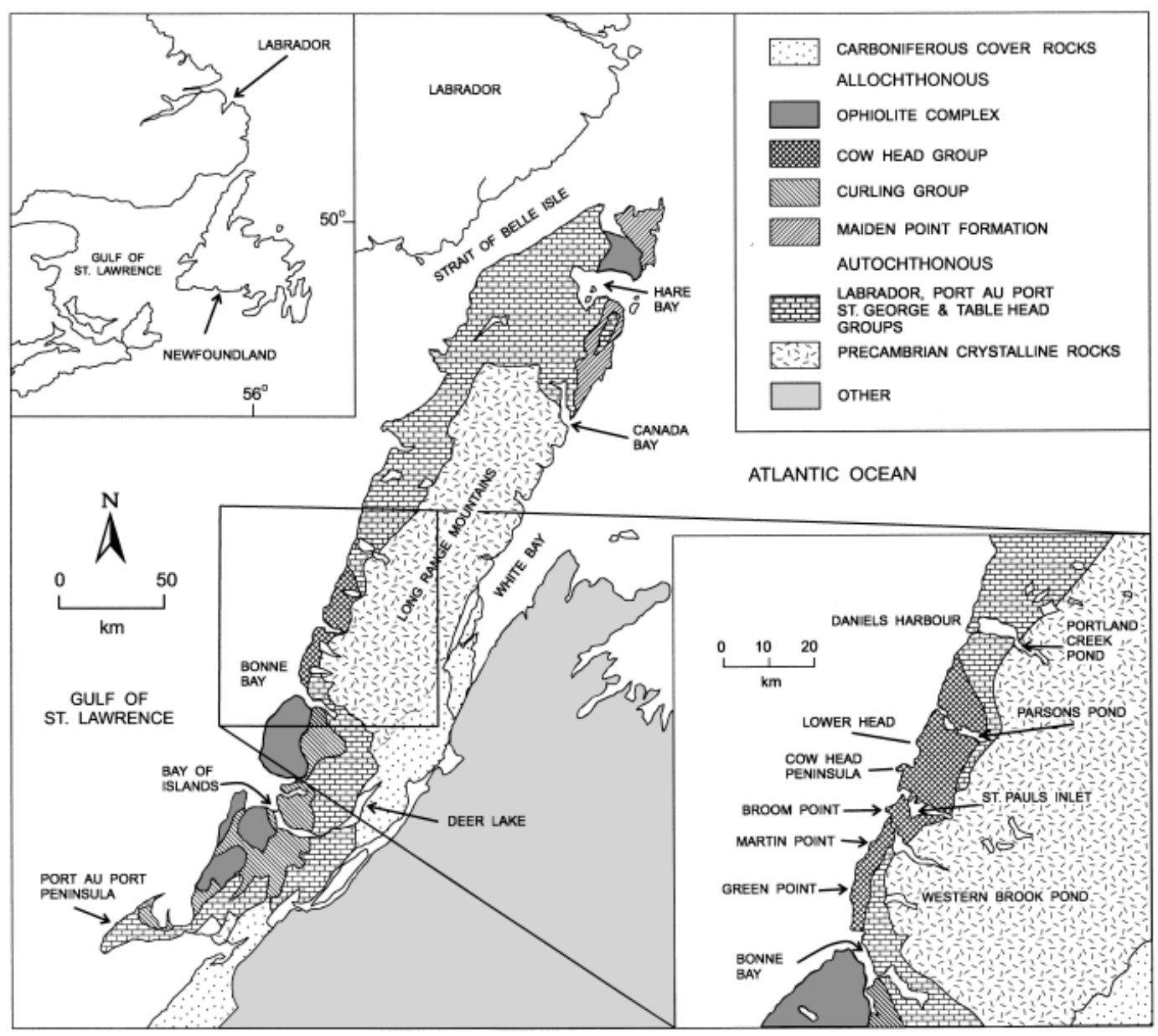

Figure 1a Location of Cow Head Group and Green Point in western Newfoundland (after Barnes, 1988). 
ingly common in proximal sections. The Green Point section is the most distal and represents a base-of-slope depositional environment. It is comprised of alternating black, grey and green shale, micritic nodular and ribbon limestone and grainstone (Figures 2, 3). Limestone conglomerate is largely confined to one bed (Bed 19) and a lenticular bed within Bed 25.

The section, which is free from unconformities, ranges from Trempealeau Series (Late Cambrian) or older to Arenig (Early Ordovician) and is over $400 \mathrm{~m}$ thick. The boundary interval discussed here is $60 \mathrm{~m}$ thick. Beds dip uniformly to the southeast at $60-70^{\circ}$ and are overturned. A few faults offset the sequence but displacements are small and readily detectable. The beds are unmetamorphosed; the conodont colour alteration index (CAI) is 1.5. Preservation of conodonts, graptolites and other fossils is excellent. Conodonts were collected from 77 levels and yielded over 9,400 elements (Barnes, 1988) while graptolites were collected from numerous bedding planes grouped into 25 main levels (Cooper et al., 1998) yielding specimens in the thousands. The conodont succession has been faithfully reproduced in several reiterative sampling sessions, mainly by Barnes (1988 and later) and most recently by Nowlan (1997). The graptolite succession is one of the most complete and well represented early Tremadoc sequences in the world, providing an exceptional 'profile' through the rapidly evolving Rhabdinopora flabelliformis complex (Erdtmann, 1988, Cooper et al., 1998).

The chosen level is based on a distinctive, pandemic conodont species about which there is little or no taxonomic controversy. At Green Point it lies just $4.8 \mathrm{~m}$ (not $4.7 \mathrm{~m}$ as reported in Cooper \& Nowlan, 1999) below the first appearance of planktic graptolites (base of the Rhabdinopora praeparabola Zone) so that, in shale successions, the FAD of planktic graptolites can be taken as a reasonable proxy for the boundary and, therefore, both conodonts and graptolites can be used in its correlation. It can thus readily be correlated directly among both carbonate and shale successions.

Other microfossil groups present are acritarchs, chitinozoans and scolecodonts (Williams, 1997), and brachiopods and radiolaria have been reported by Barnes (1988). The stratigraphic utility of these groups has yet to be determined. Shelly fossils are rare and largely uninvestigated at Green Point, however, trilobites and other shelly fossils are known from adjacent, more upslope sections (e.g. Fortey et al., 1982).

Wide coastal platform and cliff-base exposures (Figure 5) provide plenty of outcrops for studying the lithological and faunal sequence and sedimentology and for collection of samples for biostratigraphy, magnetostratigraphy and other purposes. The boundary horizon itself is exposed in the platform for over $100 \mathrm{~m}$ along strike.

The section is reached via Highway 430 and lies about $70 \mathrm{~km}$ from Deer Lake Airport and about 10 kilometres north of the village of Rocky Harbour which has hotel accommodation. The section is not in danger of deterioration or destruction from natural processes and it lies within the Gros Morne National Park (a World Heritage site) so that appropriate protection and preservation are assured. Further research on the section can be undertaken with the Park authority's approval. With the cooperation of Parks Canada, a permanent marker is currently being installed.

The Green Point section satisfies the requirements for a GSSP set out in the revised Guidelines for the establishment of global chronostratigraphic standards (Remane et al., 1996):

\section{Geological requirements}

- exposure over an adequate thickness

- continuous sedimentation

- sufficiently rapid sedimentation rate

- absence of metamorphism and strong diagenesis

Biological requirements

- abundance and diversity of well preserved fossils

- absence of vertical facies changes

- favourable facies for long-range correlation

Other requirements and desirable attributes

- suitability for radio-isotope dating, magnetostratigraphy, chemostratigraphy, sequence stratigraphy is desirable

- indication by a permanently fixed marker

- avoidance of very remote locations

- free access by researchers regardless of nationality 


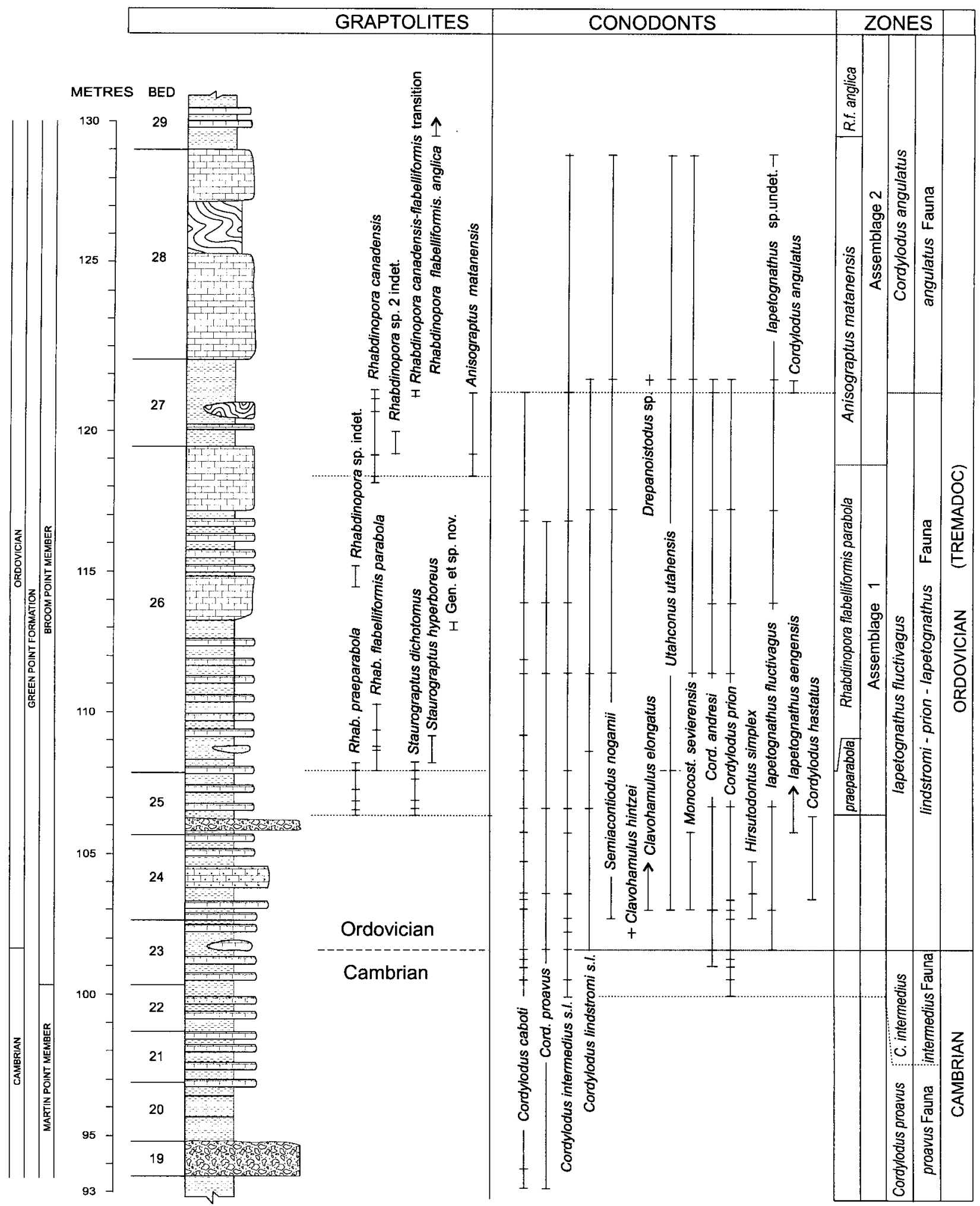

Figure 2 Stratigraphic column for the Green Point section. Graptolite ranges from Cooper et al. (1998) and Erdtmann (1985). Conodont ranges from Barnes (1988) and Nowlan and Barnes (1996), and Nowlan (1997); selected taxa and levels shown. Lithology from Erdtmann, 1985 and S.H. Williams (unpublished). Meterage used in this column is that of Erdtmann (1986) and Cooper et al. (1998). 

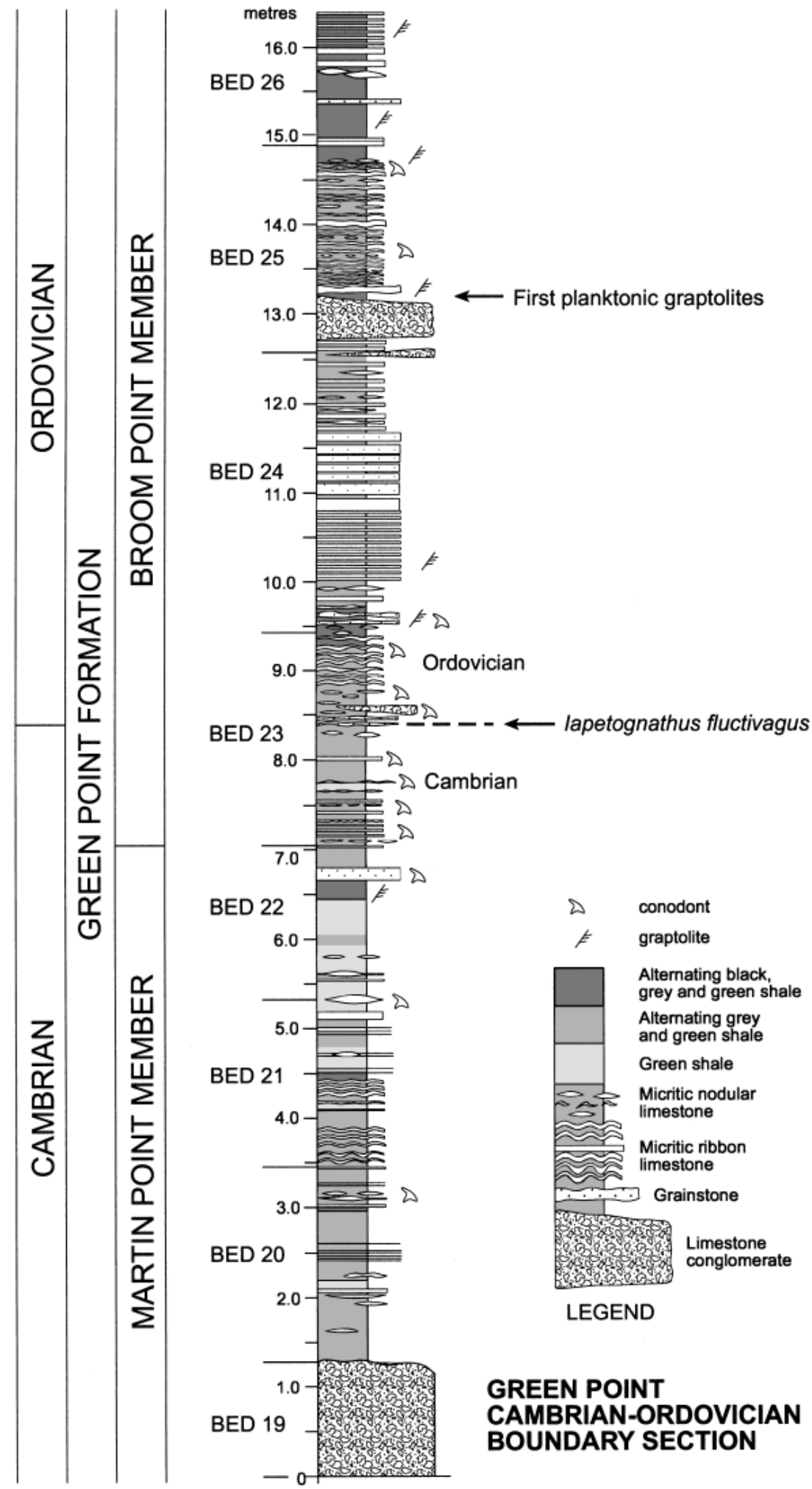

Figure 3 Detailed stratigraphic column of the boundary interval prepared by $S$. H. Williams, showing position of graptolite occurences and the conodont samples collected by $S . H$. Williams and examined by Nowlan (1997).

- free access for research, permanent protection of site

The chemostratigraphy of the section, based on a $\delta^{13} \mathrm{C}$ profile, appears to have most of the features seen in other sections across the Cambrian-Ordovician boundary, but there is extreme scatter in some of the data, possibly due to contamination from organic-rich shale units (Ripperdan, 1995). A marked negative excursion in the data near the base of the section (i.e. below the proposed boundary) correlates well with excursions found elsewhere and thus provides a firm correlation in this interval in which conodonts are only locally abundant. The section appears to be suitable for directly establishing a magnetic reversal stratigraphy across the boundary (Barnes, 1988) but as yet there are no published studies. Volcanogenic deposits suitable for direct radio-isotope dating are not yet known in the section. The sequence stratigraphy of the section has yet to be analyzed.

The Green Point section was one of 3 investigated in detail, the others being Dayangcha (northwest China) and Lawson Cove (western USA). Apart from the general problems in selection of a GSSP outlined below, all three candidates considered by COBWG since 1994 had specific disadvantages of various sorts. Although the Green Point section provides a sound GSSP, one disadvantage is the lack of diversity in conodont faunas below Bed 23. However, the most contentious issue probably is the question of whether or not the conodont biostratigraphy has been significantly altered by sedimentary reworking at Green Point. Critics point to the presence of trilobites in pebbles in the conglomerate beds at several of the western Newfoundland sections as clear indication of fossil reworking, and Miller (1997a; 1997b) has claimed that the difference between Green Point and shallow shelf sections like Lawson Cove, in stratigraphic range of conodont species, is prima facie evidence for reworking, at least of the shallow water species.

The presence of rare specimens of conodonts such as Clavohamulus and Hirsutodontus, considered to be shallow water genera, in the deep water Green Point environment, may well indicate reworking of shallow water species and these taxa should be used only with caution when correlating the section. But the plexus of species that has been focussed on for definition of the boundary - the denticulate conodonts including Cordylodus and Iapetognathus - was inhabitants of both shallow and deep water environments and are thought to have evolved in deep water. Rather than having been reworked into higher stratigraphic levels, these taxa may well, as thought by Bagnoli and Stouge (1997), appear earlier in deep water sequences than those of the shelf. The difference in stratigraphic range may therefore be due to facies control on distribution in the shallow water facies rather than to reworking in the deep water facies. 


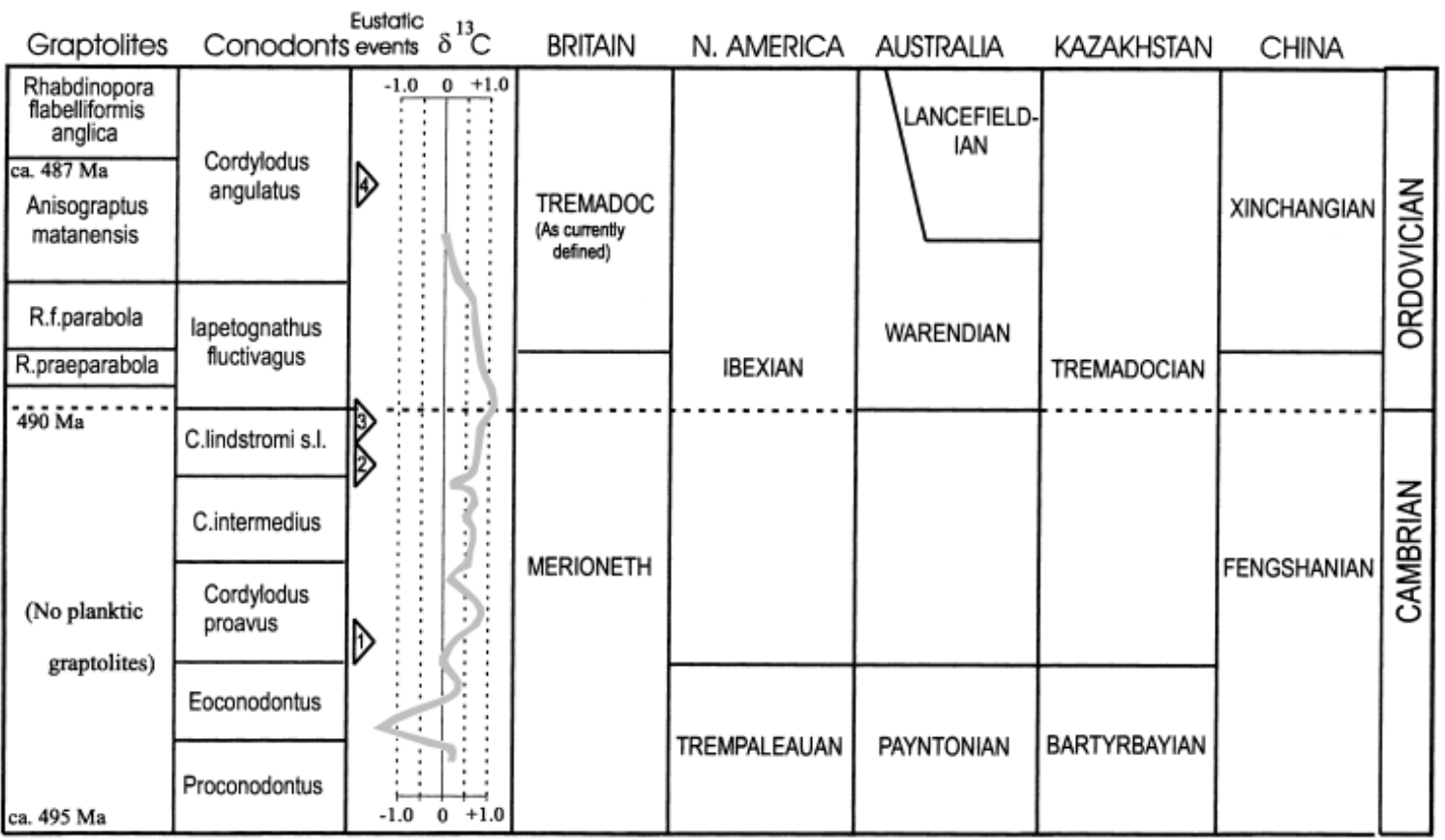

Figure 4 Correlation of proposed boundary for the base of the Ordovician System. Eustatic events are numbered: 1. Lange Ranch Eustatic Event (multiple event); 2-3. Acerocare Regressive Event (multiple event); 4. Black Mountain Regressive Event. Generalized $\delta^{13}$ C curve based on data in Ripperdan et al. 1992, 1993, and Ripperdan and Miller, 1995.

Further, biostratigraphic correlations tied to first appearance events (range bases) will not normally be affected by reworking and first appearance events should therefore be preferred for correlation. Also, in the Ordovician part of the section, a check on sediment reworking is provided by graptolites with delicate rhabdosomes that can not be reworked without at least partial, and obvious, destruction. There is no question that the numerous beds with well preserved graptolites have not been reworked at Green Point.

\section{Key fossil groups - Conodonts}

For international biostratigraphic correlation of rocks in the boundary interval, the two most important fossil groups have proved to be conodonts and graptolites. Conodonts (Figure 6) have proved reliable for global correlation of carbonate sequences and span the boundary interval. Although there are difficulties yet to be overcome (see below), they also provide the best means of correlating from shelf to deep water sequences, particularly in the late Cambrian. However, they are easily reworked by sedimentary processes.

Iapetognathus fluctivagus The conodont group identified as having best potential for use as primary guide in boundary definition by COBWG I (i.e. up to 1993) was the denticulate conodont group, the cordylodans. Although this group is still regarded by many as one of the best for correlation (e.g. Nicoll, 1990; 1992), it soon became apparent that considerable taxonomic clarification was required before the group could be utilized unambiguously. For this reason COBWG II focused on a different, but related denticulate group, including the genus Iapetognathus.

A full review of the genus Iapetognathus Landing and related forms (Nicoll et al., 1999) has established one new genus (Iapetonudus) and three new species of Iapetognathus (Ig. fluctivagus, Ig. jilinen-
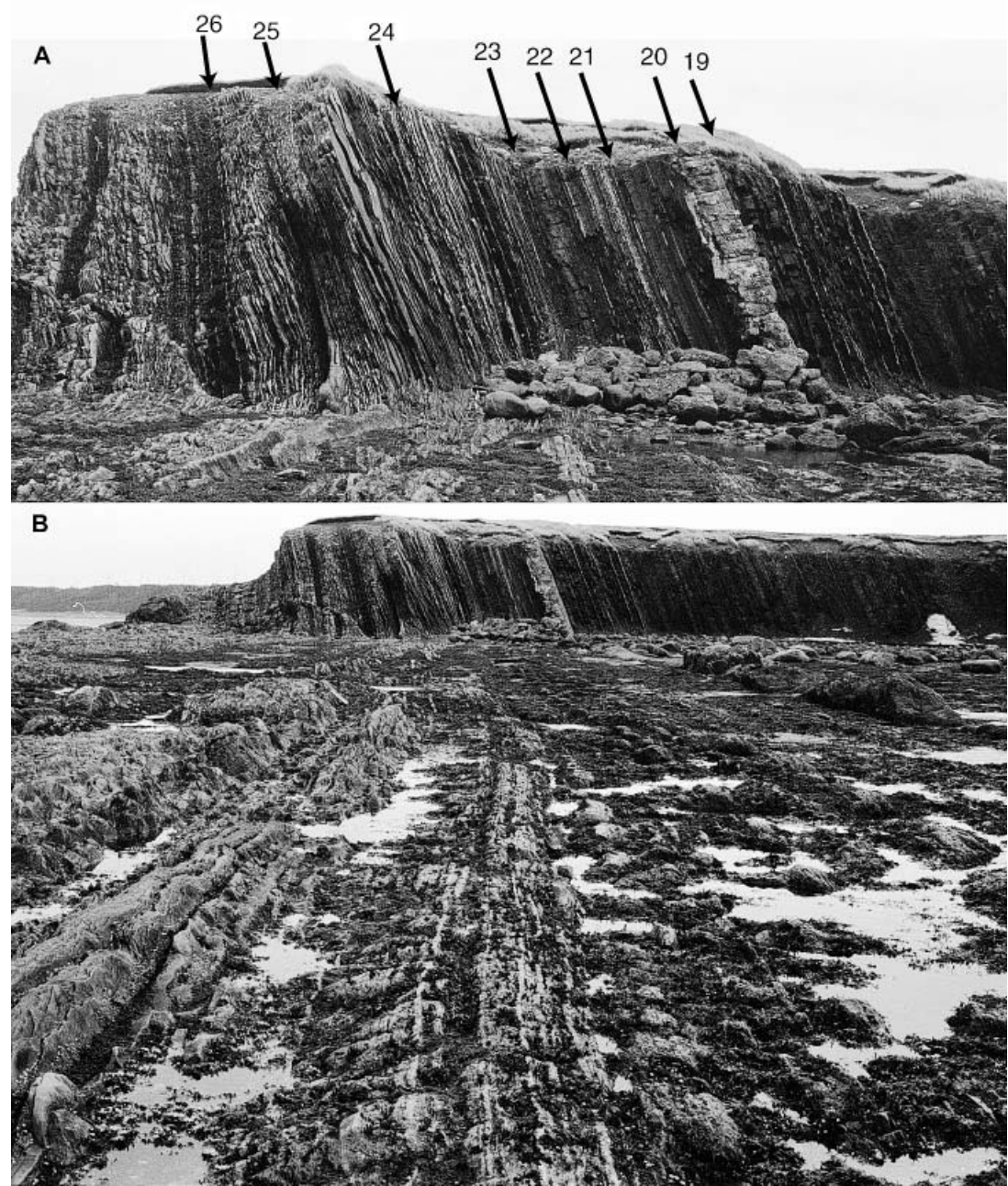

Figure 5 Photos of outcrop at Green Point. A, Close-up of critical interval with bases of units marked; $B$, broader view showing wide extent of outcrops in cliff and wavecut platform. 


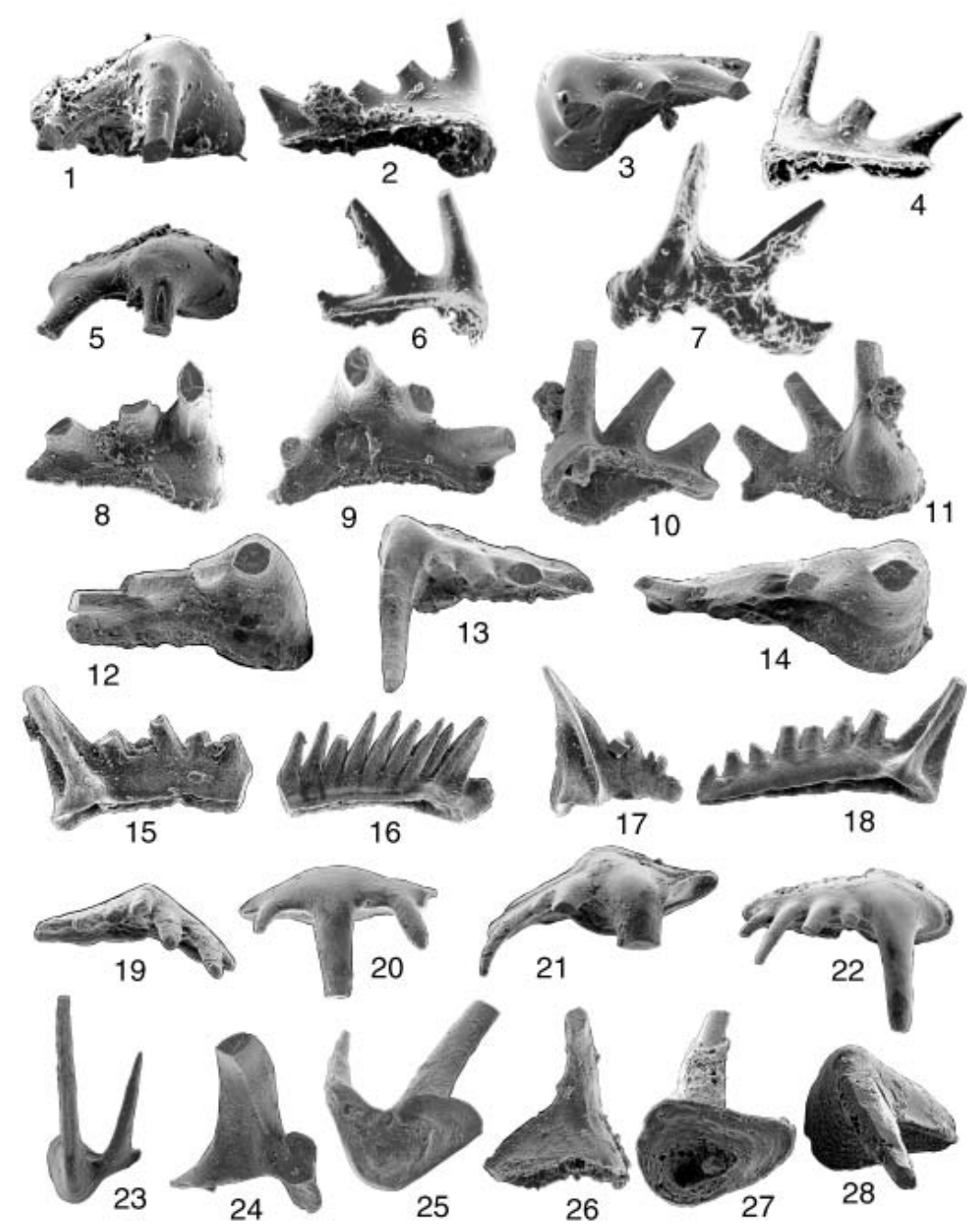

sis and Ig. landingi). Other species include Ig. sprakersi Landing and Ig. aengensis (Lindström), type species. The genus Iapetognathus is one of the earliest denticulate conodont genera known. It has a ramiform-ramiform apparatus structure and is readily distinguished from coeval denticulate multi-element genera (Eodentatus, Cordylodus) by the lateral orientation of the major denticulate process. It is believed to have evolved from the coniform-coniform apparatus Iapetonudus ibexensis Nicoll et al. The genus is global in its distribution and a succession of species first appearances seems to hold in areas with the most diverse species representation, although not all species are represented in all regions (Nicoll et al., 1999).

The species chosen for boundary definition is Iapetognathus fluctivagus (Figure 6). As known at present, its first appearance lies below other species of the genus. It is known from many sections in the western USA (Utah, Nevada, Idaho, Colorado, Oklahoma, Texas, New Mexico), western Newfoundland and British Columbia in Canada, Bartyrbay (Kazakhstan), and Wushan section, Hebei Province, China. It is found in a variety of facies and depositional environments ranging from shallow shelf to lower continental slope, in middle to low paleolatitude regions. Because species of the genus
Figure 6 Plate illustrating a variety of forms of Iapetognathus Landing and Iapetonudus Nicoll, Miller, Nowlan, Repetski and Ethington n. gen. Specimens are deposited with the Geological Survey of Canada (GSC) and the United States National Museum (USNM).

1-4, 6, 7 Iapetognathus fluctivagus n. sp. from the Green Point section, Newfoundland, Canada. 1, Sc element, oral view, $\times 89$, Bed 23, sample 34 of Barnes (1988), GSC 117142; 2 , Sc element, posterior view, $\times 61$, Bed 23 , sample 34 of Barnes (1988), GSC 117143; 3, Sc? element, oral view, $\times 70$, Bed 23, sample 34 of Barnes (1988), GSC 117144; 4, Sc element, posterior view, $\times 83$, Bed 23, GSC 117145; 6, Sc element, posterior view, $\times 66$, Bed 23, GSC 117146; 7, anterior view, Sd? element, $\times 83$, Bed 23, GSC 117147.

5, 8-11 Iapetognathus fluctivagus n. sp. from the 438 foot level of the Lawson Cove section, Utah, U.S.A. (Miller and Taylor, 1995). 5, Sc element, oral view, X185, USNM 498933; 8, $\mathrm{Pb}$ element, posterior view, X78, USNM 498951; 9 , Sd element, posterior view, $\times 75$, USNM 498943; 10, 11, Sc element, posterior and anterior views, $\times 72$, USNM 498937.

12-14 Iapetognathus jilinensis n. sp. from sample HDA 14 2 in the Xiaoyangqiao section, Dayangcha, Jilin Province, China (Chen and Gong, 1986, Table 17). 12, Sc element, oblique oral-posterior view, $\times 48$, USNM 498965; 13, Sb element, oral view, $\times 33$, USNM 498967; 14, Pb element, oral view, $\times 89$, USNM 498971.

15-18 Iapetognathus landingi n. sp. from Bed 6 of the Manitou Formation, Missouri Gulch Section, Colorado, U.S.A. (Berg and Ross, 1959; Seo and Ethington, 1993). 15 , Sb element, inner lateral view, $\times 69$, USNM 498978; 16, Xa element, inner lateral view, $\times 53$, USNM 498986; 17, Sd element, inner lateral view, $\times$ 48, USNM 498982; 18, Sc element, inner lateral view, $\times 72$, USNM 498977.

19-22 Iapetognathus aengensis (Lindström) from the Ceratopyge Limestone at the Änga Quarry, Stora Backor, Västergötland, south central Sweden, Bed 5 of Lindström, 1955). 19, Pa element, oral view, $\times$ 46, USNM 498932, 20 , Pb element, oral view, $\times 41$, USNM 498929; 21 , Sd element, oral view, $\times 33$, USNM 498925; 21, Sc element, oral view, $\times 33$, USNM 498914

23-25 Iapetognathus sprakersi Landing from sample TC1404 in the Wilberns Formation, Threadgill Creek Section, Llano Uplift, Texas, U.S.A. (Miller et al., 1982). 23, Sc element, oblique anterior-oral view, $\times 77$, USNM 498998, 24, Sd element, oblique outer lateral view, $\times 48$, USNM 499002; 25, Sc element, basal view, $\times 66$, USNM 499000.

26-28 Iapetonudus ibexensis gen. \& sp. nov. from the Lawson Cove Section, Ibex area, Utah, U.S.A. 26, Sb element, posterior view, $\times 58,438 \mathrm{ft}$. level, USNM 499006; $27,28, \mathrm{~Pa}$ element, aboral and oral views, $\times 110,435 \mathrm{ft}$. level, USNM 499009.

have been little studied to date, it is likely that the full geographic range of this species will prove to be considerably greater than is presently known.

\section{Graptolites}

Planktic graptolites appear $4.8 \mathrm{~m}$. above the boundary in the Green Point section. This stratigraphic interval, which contains no significant stratigraphic breaks, can be estimated as equivalent to less than $1 \%$ of Tremadoc time (Cooper, 1991). Therefore, for most practical purposes, the first appearance level of planktic graptolites can be taken as a proxy for the boundary in shale sequences devoid of conodonts. Graptolites (Figures 7, 8) are reliable for global correlation of shale sequences, can not be readily reworked and, in favourable facies, can be used for correlation between shelf and deep water sequences. However, they are confined to the Ordovician side of the boundary.

The earliest planktic graptolite species, Staurograptus dichotomus and Rhabdinopora praeparabola, are both present in the Green 


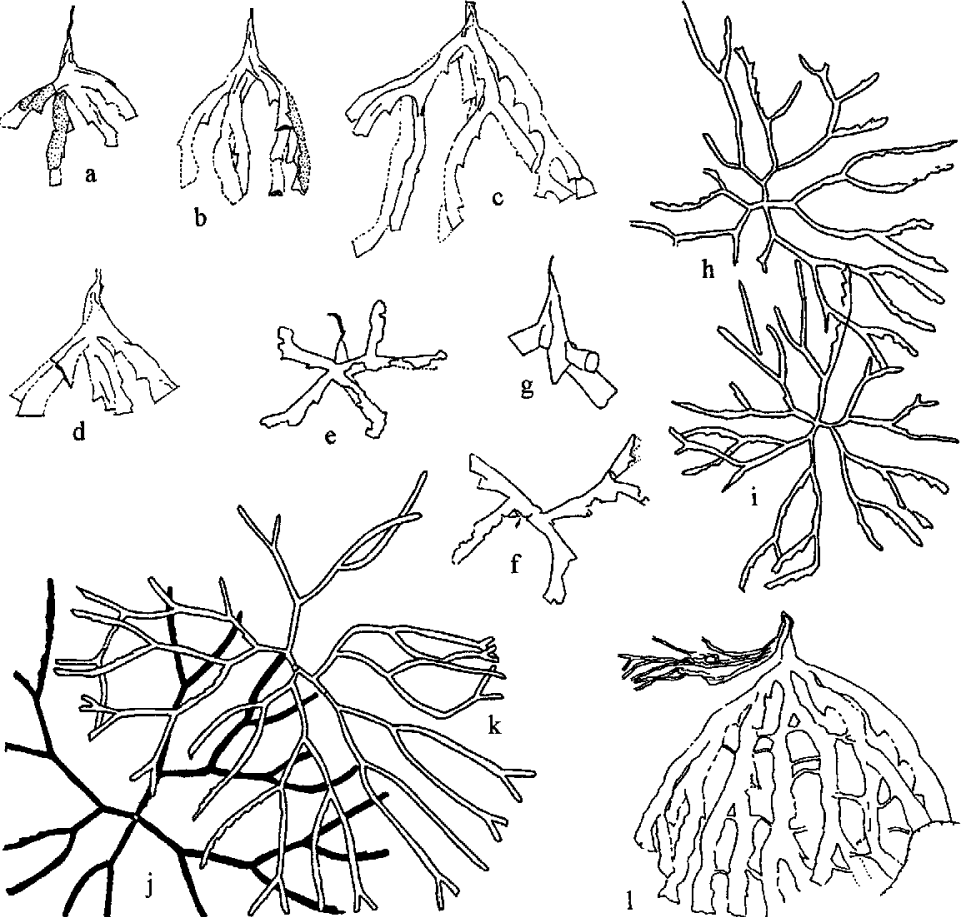

Figure 7 Earliest planktic graptolites. a-d), Rhabdinopora praeparabola Bruton, Erdtmann and Koch 1982, immature rhabdosomes showing proximal details; a) GSC 115800, b) GSC 115801, c) GSC 115802, d) PMO 155.447; $e-k)$, Staurograptus dichotomous Emmons, growth stages (e-g) and mature rhabdosomes (h-k); e) GSC 115834, f) GSC 115835, g) GSC 115831, h) GSC 115837, i) GSC 115838, j) GSC 115847, k) GSC GSC 115846, l) Rhabdinopora flabelliformis parabola, incompletely grown specimen with divided nema, PMO 155.450. a-d) $\times 4.1 ; e-f) \times 4 ; g) \times 7.3 ; h-k) \times 1.8 ; l) \times 6$. All specimens are from Green Point except for $7 d$ and $7 l$ which are from Digermul Peninsula, northern Finnmark. All figures from Cooper et al. (1998).

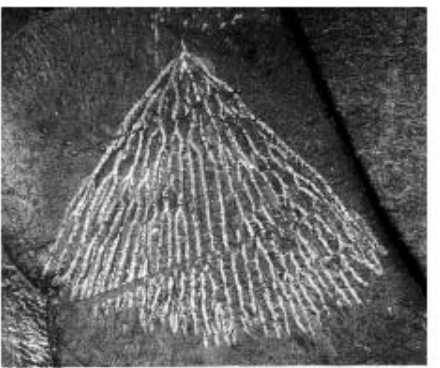

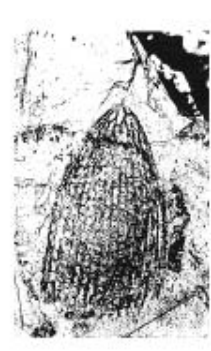

b

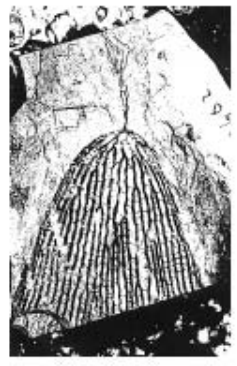

c
Figure 8 a) Rhabdinopora flabelliformis flabelliformis (Eichwald 1840), immature specimen, LO7511 from Öland, Sweden, $\times 0.9 ; b-c)$, Rhabdinopora flabelliformis parabola (Bulman 1954), mature specimens from Dayangcha, China (NIGPAS 92667 and NIGPAS 92662 respectively), $\times 1.2$.

Point section. The following succession of Rhabdinopora species and subspecies represents an evolutionary complex with global distribution. The genus is diverse, composed of intergrading populations, each characteristic of a particular horizon (stratigraphic subspecies ) or ecological zone (ecological subspecies). Four biostratigraphic zones are recognized in the Early Tremadoc, the Zones of Rhabdinopora praeparabola, $R$. flabelliformis parabola, Anisograptus matanensis, Rhabdinopora flabelliformis anglica, in upward sequence. Within each of the upper 3 zones, subspecies are partitioned into shelf, upper slope, lower slope and ocean floor assem- blages. The succession of subspecies preserved at any one site in the shelf and upper slope environments reflects the interplay of evolutionary change and migrating biofacies with sea level change. The biostratigraphic/ecological scheme enables fine correlation of the earliest Ordovician (Cooper, 1999).

\section{Other fossil groups}

Trilobites enable fine subdivision and correlation of platform sequences, and olenid trilobites enable correlation with deeper water successions. The boundary closely coincides with the first appearance of the trilobites Jujuyaspis borealis and Symphysurina bulbosa at the base of the $S$. bulbosa Subzone of North America (Miller and Stitt, 1995). Brachiopods and other shelly groups are most useful for intra-regional correlation. Correlation based on organic walled microfossils is still largely undeveloped but one group that shows promise is acritarchs (Martin, 1982).

The most difficult problem in biostratigraphic correlation of the boundary interval is not due to regional provincialism but to strong facies differentiation. Working Group papers presented in the two volumes on the boundary mentioned above, and Cooper (1999), show that relatively precise correlation of the boundary interval, at the zonal level, can now be achieved between continents within shelf carbonate successions using conodonts and trilobites, or within slope-basin successions using graptolites and conodonts. But correlating between shelf and basin sequences, even when they lie adjacent to each other on the one continent, remains difficult. The key fossil group for pan-facies correlation of the boundary is conodonts but deep water (slope and basin) conodont successions are relatively poorly known, the best by far being the Green Point sequence. It is therefore uncertain whether observed differences in the succession of some species between the Green Point sequence and shallow shelf sequences such as the Lawson Cove sequence are due to a sedimentological cause such as reworking or to facies control on stratigraphic range. Considerably more research is required to resolve this question. The problem is greater in the Late Cambrian than in the early Ordovician where graptolites evolved rapidly and invaded the shelf environment providing an additional, precise, correlation tool.

\section{Correlation of the boundary}

Correlation of the proposed boundary is shown in Figure 4. The boundary lies just below the base of the Tremadoc Series as traditionally defined (Rushton 1982). It lies in the lower Ibex Series of North America (Ross et al., 1997), at the base of the Warendian Stage of north Australia (Shergold and Nicoll, 1992), in the lower Tremadoc as used in Kazakhstan (Apollonov et al., 1988), and in the late Fengshanian of north China. In terms of conodont zones (Miller 1988, Miller and Stitt 1995, Nicoll et al., 1999) the boundary coincides with the base of the Iapetognathus Zone. 
1998) and provides a maximum age constraint on the boundary. Together with the other Cambrian and Ordovician zircon dates (Tucker and McKerrow, 1995; Perkins and Walshe, 1993; Encarnación et al., 1999; Landing et al., 1997) the new dates suggest an age for base of the Ordovician no older than, and close to, $490 \mathrm{Ma}^{*}$.

\section{Carbon isotopes}

Among the more promising physical tools for boundary correlation among carbonate-bearing sections is carbon isotope $\left(\delta^{13} \mathrm{C}\right)$ chemostratigraphy. Unlike most chemostratigraphic markers, $\delta^{13} \mathrm{C}$ values are relatively insensitive to many post-depositional processes because of the extremely low abundance of carbon in water relative to carbonate rock (Magaritz 1983; Banner and Hanson 1990). Work by R. Ripperdan and colleagues shows that remarkably comparable curves reflecting shifts in $\delta^{13} \mathrm{C}$ can be obtained for carbonate sequences spanning the boundary interval on different continents (Ripperdan, 1995; Ripperdan and Miller, 1995; Ripperdan et al., 1992, 1993). Curves have been established for carbonate sections at Bartyrbay Ravine (Kazakhstan), Black Mountain (Australia), Lange Ranch (Texas), Lawson Cove (Utah), Dayangcha (China). At Green Point, the data are more scattered, possibly due to isotopic contamination from organic-rich shales during immediate post depositional diagenesis. As a result, the curve is less well established, but some of the main $\delta^{13} \mathrm{C}$ excursions are identifiable.

In general, the global trend shows minimum values near the base of the Cambrooistodus minutus Zone after which values rise sharply, representing a shift of $1-2 \%$. Two main positive cycles are present between the base of the Cordylodus proavus Zone and base of the $C$. lindstromi sensu lato Zone in many sections. In the Iapetognathus Zone, $\delta^{13} \mathrm{C}$ rises rapidly to reach its highest value in the boundary interval, before dropping rapidly, and continuing to fall through the $C$. angulatus Zone.

The chosen boundary level therefore coincides closely with the peak of a positive cycle in $\delta^{13} \mathrm{C}$ (\%o vs. PDB), representing the highest value reached in the boundary interval. This should be a useful correlation datum.

\section{Magnetostratigraphy}

As yet there is no standardized magnetostratigraphy through the boundary interval, (i.e. verified in several sections). Magnetostratigraphic reversal stratigraphy has been obtained from several sections, including Black Mountain, Dayangcha, several sections in western Newfoundland including Green Point, Bartyrbay, and Texas (Ripperdan and Kirschvink, 1992; Kirschvink et al., unpublished). In general, the geomagnetic field had predominantly reversed polarity throughout the boundary interval. In the Late Cambrian, short intervals of normal polarity are present in the late Proconodontus and late Eoconodontus Zones and appear to have good value for correlation. In the Early Ordovician, short intervals of normal polarity are present but are currently difficult to correlate. The low conodont colour alteration index (CAI) values for some western Newfoundland rocks, including those of Green Point (Nowlan and Barnes, 1987), and the preliminary work done so far, suggest that these rocks are Early Tremadoc graptolitic bioevents and sea level events is discussed by Cooper (1999).

* Since submission of this MS, an age for the lower boundary of the Ordovician System close to $490 \mathrm{Ma}$ has been supported by Landing, et al. (2000) who have dated zircons in two thin volcaniclastic bands immediately underlying the base of the Ordovician in the Bryn-lln farw section, North Wales, indicating that the base is no old than $489 \pm 0.6 \mathrm{Ma}$. (Landing, E. S. A., Bowring, K. L., Davidek, K. L., Rushton, A. W. A., Fortey, R. A. and Wimbledon, A. P., 2000. Cambrian-Ordovician boundary age and duration of the lowest Ordovician Tremadoc series based on U-Pb zircon dates from Avalonian Wales. Geological Magazine 137:485-494).

\section{Name of earliest Ordovician stage}

The International Subcommission on Ordovician Stratigraphy voted in 2000 to approve the name, Tremadocian, for the earliest Ordovician stage. The stage extends from the level of the first appearance of the conodont, Iapetognathus fluctivagus, in the Green Point section of western Newfoundland (base of the Ordovician) up to the level of the first appearance of the graptolite, Tetragraptus approximatus, in which ever section is chosen as GSSP for the base of the second Ordovician stage.

\section{International boundary working groups (COBWG I, COBWG II)}

The International Working Group on the Cambrian-Ordovician Boundary (COBWG I) was established in 1974, with 14 voting members and more than 50 corresponding members, under the Chairmanship of G. Henningsmoen (Norway). Over the following 19 years the Working Group issued 31 Circulars with description and discussion of candidate sections and levels, and debate on boundary definition issues, principles and procedures. The Group visited candidate sections in Kazakhstan, China, Australia, Scandinavia, Britain and North America. Two volumes of papers on candidate boundary sections were published (Bassett and Dean, 1982 and a special 1988 issue of Geological Magazine, v. 125 no. 4). In addition, two volumes of papers on the Dayangcha section alone have been published (Chen et al., 1985; 1986). In 1976 W.T. Dean (United Kingdom) succceeded Henningsmoen as Chairman; in 1980 he in turn was succeeded by B.S. Norford (Canada) and the number of titular members was increased to 17 . The executive and voting members of this first Working Group (COBWG I) retired in 1993.

Later in 1993 a new group of 13 titular members (COBWG II) was formed, and in December of that year the group elected R.A. Cooper (New Zealand) as Chairman and G.S. Nowlan (Canada) as Secretary. From 1994 to 1998 the new Group issued 6 Circulars and a number of information letters and undertook detailed investigations into the Dayangcha, Green Point and Lawson Cove candidate sections. Altogether, 15 formal ballots have been held by the two Groups. A full summary of the activities, deliberations and formal decisions of the two Groups is given in Appendix 1 of the report submitted to the Subcommission on Ordovician Stratigraphy in March 1999. The decision to recommend the Green Point section and point or GSSP for base of the Ordovician System was approved by $77 \%$ of Voting Members.

\section{Voting members, 1974}

$\begin{array}{ll}\text { J.W. Cowie } & \text { B.S. Norford } \\ \text { R.A. Cooper } & \text { R.J. Ross } \\ \text { W.T. Dean } & \text { K. Sdzuy } \\ \text { E.C. Druce } & \text { J.H. Shergold } \\ \text { G. Henningsmoen (Chairman) } & \text { D. Skevington } \\ \text { D.E. Jackson } & \text { M.E. Taylor } \\ \text { J.F. Miller } & \text { H.B. Whittington }\end{array}$

Voting members, 1989

$\begin{array}{ll}\text { M.K. Apollonov } & \text { Lu Yanhao } \\ \text { Chen Jun-yuan } & \text { J.F. Miller (Secretary) } \\ \text { R.A. Cooper } & \text { B.S. Norford (Chairman) } \\ \text { J.W. Cowie } & \text { R.J. Ross } \\ \text { W.T. Dean } & \text { J.H. Shergold } \\ \text { B-D. Erdtmann } & \text { D. Skevington } \\ \text { G. Henningsmoen } & \text { M.E. Taylor } \\ \text { D. Kaljo } & \text { H.B. Whittington }\end{array}$


Voting members, 1993-98

Chen Jun-yuan
R.A. Cooper (Chairman)
S.V. Dubinina
B-D. Erdtmann
R.L. Ethington
R.A. Fortey
D. Kaljo

R.S. Nicoll

G.S. Nowlan (Secretary)

R. Ripperdan

A.W.A. Rushton

J.H. Shergold

J.F. Taylor

\section{Acknowledgements}

We acknowledge the contributions to the work of the Working Group made by many voting and corresponding members since 1974. Much of this work is recorded in the pages of over 30 Circulars produced by COBWG I, and 6 Circulars produced by COBWG II. Some, but not all, of it has been published and is known to the wider geological community. We thank Prof. Chris Barnes for his help in giving access to all existing data on Green Point, and acknowledge the contribution of Dr Bob Nicoll and his co-authors for clarifying taxonomic relationships of conodonts. We also acknowledge the co-operation of the staff of Gros Morne National Park in designation and recognition of the Green Point section as a protected scientific site of international importance. Denise Then of the Geological Survey of Canada used her considerable skills to produce the final versions of some of the figures.

\section{References}

Appollonov, M.K., Chugaeva, M.N., Dubinina, S. V. and Zhemchuzhnikov, V. G., 1988, Batyrbay Section, South Kazakhstan, U.S.S.R. - potential stratotype for the Cambrian-Ordovician boundary: Geological Magazine, v. 125 , pp. $445-449$.

Bagnoli, G. and Stouge, S., 1997, Commentary on Iapetognathus: International Cambrian-Ordovician Boundary Working Group Circular November 1997, pp. 10-14.

Bagnoli, G., Barnes, C.R., and Stevens, R.K., 1987, Tremadocian conodonts from Broom Point and Green Point, western Newfoundland: Bollettino della Societa Paleontologica, v. 25, pp. 145-158.

Banner, J.L., and Hanson, G.N., 1990, Calculation of simultaneous isotopic and trace element variations during water-rock interaction with application to carbonate diagenesis: Geochimica et Cosmochimica Acta, v. 54, pp. 3123-3137.

Barnes, C.R., 1988, The proposed Cambrian-Ordovician global boundary stratotype and point (GSSP) in western Newfoundland, Canada: Geological Magazine, v. 125, pp. 381-414.

Bassett, M.G. and Dean, W.T., 1982, Editors, The Cambrian-Ordovician Boundary: Sections, Fossil Distributions and Correlations: National Museum of Wales, Geological Series, No. 3, 227 pp.

Chen, Jun-yuan., Qian, Yi-yuan, Lin, Yao-kun, Zhang, Jun-ming, Wang, Zhihao., Yin, Lei-Ming and Erdtmann, B.-D., 1985, Study on CambrianOrdovician boundary strata and its biota in Dayangcha, Hunjiang, Jilin, China. (Contribution to the Calgary Cambrian-Ordovician Boundary Meeting): China Prospect Publishing House, 138 pp., 39 pls., Beijing, 1985.

Chen Jun-yuan, Qian Yi-yuan, Zhang Jun-ming, Lin Yao-kun, Yin Lei-ming, Wang Zhi-hao, Wang Zong-zhi, Yang Jie-dong, and Wang Ying-xi, 1988, The recommended Cambrian-Ordovician global boundary stratotype of the Xiaoyangqiao section (Dayangcha, Jilin Province), China: Geological Magazine, v. 125(4), pp. 415-444.

Chen Jun-yuan, Zhang Jun-ming, Nicoll, R.S., and Nowlan, G.S., 1995, Carbon isotopes in the carbonate rocks within the Cambrian-Ordovician boundary interval at Dayangcha, China: Acta Paleontologica Sinica, v. 34, pp. 393-409.

Cooper, R.A. 1996, Correlation of Dayangcha, Lawson Cove and Green Point sections: International Cambrian-Ordovician Boundary Working Group, Circular May 1996, Attachment 5.

Cooper, R.A., Maletz, Jörg, Wang Haifeng, and Erdtmann, B.-D., 1998, Taxonomy and evolution of earliest Ordovician graptolites: Norsk Geologisk Tiddskrift, v. 78, pp. 3-32.

Cooper R.A., 1991, Ecostratigraphy, zonation and global correlation of earliest planktic graptolites: Lethaia, v. 32, pp. 1-16.
Davidek, K., Landing, E., Bowring, S.A., Westrop, S.R., Rushton, A.W.A., Fortey, R.A. and Adrain, J.M., 1998, New uppermost Cambrian U-Pb date from Avalonian Wales and age of the Cambrian - Ordovician boundary: Geological Magazine, v. 135, pp. 305-309.

Erdtmann, B.-D. 1986, Early Ordovician eustatic cycles and their bearing on punctuations in early nematophorid (planktic) graptolite evolution, in Walliser, O.H. (editor), Lecture Notes in Earth Sciences, Volume 8: Global Bioevents, pp. 139-152.

Erdtmann, B.-D. 1988, The earliest Ordovician nematophorid graptolites: taxonomy and correlation, Geological Magazine, v. 125 , pp. 327-348.

Fåhraeus, L.E. and Nowlan, G.S., 1978, Franconian (Late Cambrian) to Early Champlainian (Middle Ordovician) conodonts from the Cow Head Group, western Newfoundland: Journal of Paleontology, v. 52, pp. 444471.

Fortey, R.A., Landing, E. \& Skevington, D., 1982, Cambrian-Ordovician boundary sections in the Cow Head Group, western Newfoundland, in Bassett, M.G. and Dean, W.T., editors, The Cambrian-Ordovician Boundary: Sections, fossil distributions and correlations: National Museum of Wales, Geological Series, No. 3, pp. 95-129.

James, N.P and Stevens, R.K., 1986, Stratigraphy and correlation of the Cambro-Ordovician Cow Head Group, western Newfoundland: Geological Survey of Canada Bulletin 366, 143 pp.

Magaritz, M., 1983, Carbon and oxygen isotope composition of recent and ancient coated grains, in Peryt, T.M., editor, Coated Grains: Springer Verlag, Berlin, pp. 27-37.

Martin, F., 1982, Some aspects of late Cambrian and early Ordovician acritarchs, in Bassett, M.G. and Dean, W.T., editors, The Cambrian Ordovician Boundary: Sections, fossil distributions and correlations: National Museum of Wales, Geological Series, No. 3, pp. 29-40.

Miller, J.F., 1988, Conodonts as biostratigraphic tools for redefinition and correlation of the Cambrian-Ordovician boundary: Geological Magazine, v. 125 , pp. $349-362$.

Miller, J.F., 1992, The Lange Ranch Eustatic Event: A regressive-transgressive couplet near the base of the Ordovician System, in Webby, B. D. and Laurie, J.R., editors, Global Perspectives on Ordovician Geology: A.A. Balkema, Rotterdam, 1992, pp. 395-407.

Miller, J.F., 1997a, Update on the Lawson Cove Section: International Cambrian-Ordovician Boundary Working Group, Circular January 1997, pp. 20-27.

Miller, J. F., 1997b, More discussion on problems with Green Point: International Cambrian-Ordovician Boundary Working Group, Circular November 1997, pp. 21-28.

Nicoll, R.S., 1990, The genus Cordylodus and a latest Cambrian - earliest Ordovician conodont biostratigraphy: Bureau of Mineral Resources Journal of Australian Geology and Geophysics, v. 11, pp. 529-558.

Nicoll, R.S., 1992, Evolution of the conodont genus Cordylodus and the Cambrian-Ordovician boundary, in Webby, B. D. and Laurie, J. R., editors, Global Perspectives on Ordovician Geology: A.A. Balkema, Rotterdam, 1992, pp. 105-113.

Nicoll, R.S., Miller, J.F., Nowlan, G.S., Repetski, J.E. and Ethington, R.L., 1999, Iapetonudus (New Genus) and Iapetognathus Landing, unusual earliest Ordovician multielement conodont taxa and their utility for biostratigraphy: Brigham Young University Geology Studies, v. 44, pp. $27-$ 101 .

Nicoll, R.S., Nielsen, A.T., Laurie, J.R. and Shergold, J.H., 1992, Preliminary correlation of latest Cambrian to Early Ordovician sea level events in Australia and Scandinavia, in Webby, B.D., and Laurie, J.R., editors, Global perspectives on Ordovician Geology: A.A. Balkema, Rotterdam, 1992, pp. 381-394

Nowlan, G. S., 1997, Update on the Green Point section: International Cambrian-Ordovician Boundary Working Group, Circular November 1997, p. 4-10.

Nowlan, G.S. and Barnes, C.R., 1987, Thermal maturation of Paleozoic strata in eastern Canada from conodont colour alteration index (CAI) data with implications for burial history, tectonic evolution, hotspot tracks and mineral and hydrocarbon exploration: Geological Survey of Canada Bulletin $367,47 \mathrm{pp}$.

Nowlan, G.S. and Nicoll, R.S., 1995, Re-examination of the conodont biostratigraphy at the Cambro-Ordovician Xiaoyangqiao Section, Dayangcha, Jilin Province, China, in Cooper, J.D., Droser, M.L. and Finney, S.C., editors, Ordovician Odyssey: short papers for the Seventh International Symposium on the Ordovician System: Pacific Section Society for Sedimentary Geology, Book 77, pp. 113-116.

Pohler, S.M.L., 1994, Conodont biofacies of Lower to lower Middle Ordovician megaconglomerates, Cow Head Group, western Newfoundland: Geological Survey of Canada Bulletin 459, $71 \mathrm{pp}$.

Remane, J., Bassett, M.G., Cowie, J.W., Gohrbandt, K.H., Lane, H.R., Michelson, O., Wang Naiwen, 1996, Revised guidelines for the estab- 
lishment of global chronostratigraphic standards by the International Commission on Stratigraphy (ICS): Episodes, v. 19, pp. 77-81.

Ripperdan, R.L., 1995, Variations in marine carbon isotope ratios (d13C) through the Cambrian-Ordovician boundary interval. International Cambrian-Ordovician Boundary Working Group, Circular December 1995, p. 11-20.

Ripperdan, R.L. and Kirschvink, J.L., 1992, Paleomagnetic results from the Cambrian-Ordovician boundary section at Black Mountain, Georgina Basin, western Queensland, Australia, in Webby, B.D., and Laurie, J.R., editors, Global perspectives on Ordovician Geology: A.A. Balkema, Rotterdam, 1992, pp. 381-394.

Ripperdan, R.L. and Miller, J.F., 1995, Carbon isotope ratios from the Cambrian-Ordovician boundary section at Lawson Cove, Ibex area, Utah, in Cooper, J.D., Droser, M.L., and Finney, S.C., editors, Ordovician Odyssey: short papers for the Seventh International Symposium on the Ordovician System: Special Publication Pacific Section of Economic Paleontologists and Mineralogists 77, pp. 129-132.

Ripperdan, R.L., Magaritz, M., Kirschvink, J.L., 1993, Carbon isotope and magnetic polarity evidence for non-depositional events within the Cambrian-Ordovician boundary section at Dayangcha, Jilin Province, China: Geological Magazine, v. 130, pp. 443-452.

Ripperdan, R.L., Magaritz, M., Nicoll, R.S., and Shergold, J.H., 1992, Simultaneous changes in carbon isotopes, sea level, and conodont biozones within the Cambrian-Ordovician boundary interval at Black Mountain, Australia: Geology, v. 20, pp. 1039-1042.

Ross, R.J.Jr., Hintze, L.F., Ethington, R.L., Miller, J.F., Taylor, M.E. and Repetski, J.E., 1997, The Ibexian, lowermost Series in the North American Ordovician: U.S. Geological Survey Professional Paper 1579A, pp. $1-50$.

Rushton, A.W.A., 1982, The biostratigraphy and correlation of the Merioneth-Tremadoc Series boundary in North Wales, in Bassett, M.G. and Dean W.T., editors, The Cambrian-Ordovician Boundary: Sections, Fossil Distributions, and Correlations: National Museum of Wales Geological Series 3, Cardiff, pp. 41-59.

Shergold, J.H., and Nicoll, R.S., 1992, Revised Cambrian-Ordovician boundary stratigraphy, Black Mountain, western Queensland, in Webby, B. D. and Laurie, J. R., editors, Global perspectives on Ordovician Geology: A. A. Balkema, Rotterdam, 1992, pp. 81-92.

Tucker, R.D. and McKerrow, W.S., 1995, Early Paleozoic geochronology: A review in light of new $\mathrm{U} / \mathrm{Pb}$ zircon ages from Newfoundland and Britain: Canadian Journal of Earth Sciences, v. 32, pp. 368-379.

Williams, S.H., 1997, Graptolites, acritarchs and scolecodonts at Green Point, western Newfoundland: International Cambrian-Ordovician Boundary Working Group, Circular January 1997, pp. 6-15.
Dr Roger A. Cooper, a paleontologist and program leader with G.N.S., has been Chair of COBWG since 1994. He is a graptolite specialist currently interested in macroevolution, correlation methodology and time scale development. Other research interests are Early Paleozoic terrane analysis, and tectonics of the SW Pacific. He has collaborated widely in international research projects and is a titular member of the International Subcommission on Ordovician Stratigraphy.

Dr. Godfrey S. Nowlan is a senior research scientist with the Geological Survey of Canada in Calgary, Alberta. He is a specialist in Lower Paleozoic conodonts and has worked on phosphatic microfossils of Late Precambrian through Silurian age in all geological regions of Canada. He has applied conodonts in solving problems in complex tectonic terranes, especially the Appalachian and Innuitian orogens. He has also developed biostratigraphic schemes for many basins in Canada. He has served as Secretary of Subcommission on Silurian Stratigraphy and is currently Secretary of COBWG II.

Dr. S. Henry Williams has been closely involved with the work of the Ordovician Subcommission since completion of his PhD thesis in 1983, the data of which was used in defining the Ordovician-Silurian boundary GSSP at Dob's Linn, southern Scotland. He was Secretary of the Ordovician Subcommission for eight years and has been a Professor at Memorial University of Newfoundland since 1987.
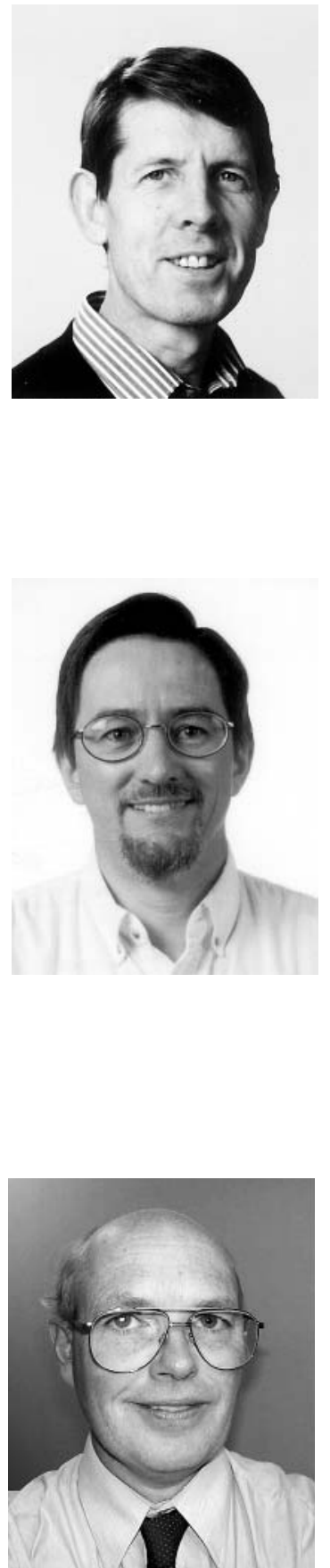